\title{
Isolation and characterization of a novel native Bacillus strain capable of degrading diesel fuel
}

\author{
${ }^{1}$ D. Yousefi Kebria; ${ }^{1 *}$ A. Khodadadi; ${ }^{1}$ H. Ganjidoust; ${ }^{1}$ A. Badkoubi; ${ }^{2}$ M. A. Amoozegar \\ ${ }^{1}$ Department of Civil Engineering, Faculty of Environmental Engineering, Tarbiat Modares University, \\ Tehran, Iran \\ ${ }^{2}$ Department of Microbiology, Faculty of Biology, University of Tehran, Tehran, Iran
}

\author{
Received 4 December 2008; $\quad$ revised 18 April 2009; accepted 14 May 2009; available online 1 June 2009
}

\begin{abstract}
The ability of native bacteria to utilize diesel fuel as the sole carbon and energy source was investigated in this research. Ten bacterial strains were isolated from the oil refinery field in Tehran, Iran. Two biodegradation experiments were performed in low and high (500 and 10000 ppm, respectively) concentration of diesel fuel for 15 days. Only two isolates were able to efficiently degrade the petroleum hydrocarbons in the first test and degraded 86.67 $\%$ and, $80.60 \%$ of diesel fuel, respectively. The secondary experiment was performed to investigate the toxicity effect of diesel fuel at high concentration (10000 ppm). Only one strain was capable to degrade $85.20 \%$ of diesel fuel at the same time (15 days). Phenotype and phylogeny analysis of this strain was characterized and identified as dieseldegrading bacteria, based on gram staining, biochemical tests, 16S rRNA gene sequence analysis. These results indicate that this new strain was Bacillus sp. and could be considered as Bacillus Cereus with $98 \% 16 \mathrm{~S}$ rRNA gene sequence similarity. The results indicate that native strains have great potential for in situ remediation of diesel-contaminated soils in oil refinery sites.
\end{abstract}

Keywords: Bacillus cereus; Bacteria; Biodegradation; Bioremediation; Petroleum

\section{INTRODUCTION}

Iran is the first country in the oil-rich Middle East region to start oil operations with current production capacities of over 4 million barrels of crude oil and $80,000 \mathrm{~m}^{3} /$ day of diesel fuel. There are up to $1,500,000$ cubic meters of soil contaminated with crude oil around the Tehran refinery, Iran. Soil and ground water are often contaminated with gasoline or diesel fuel from leaking underground storage tanks and also due to accidental spills and leakage from pipelines. Due to their mobility, these compounds may cause considerable damage not only in soils, but also in water intakes or ground water reservoirs (Gallego et al., 2001).

The carbon number of diesel oil hydrocarbons is between 11 and 25 (2000 to 4000 hydrocarbons) and the distillation range is between 180 to $380^{\circ} \mathrm{C}$ (Durand et al., 1995). Diesel oil is a complex mixture of normal, branched and cyclic alkanes and aromatic compounds with the properties of low water solubility, high adsorption coefficient and high stability of the aromatic ring (Dean et al., 2002; Kanaly and Harayama, 2002;

《*Corresponding Author Email: akdarban@modares.ac.ir Tel.: +98 218288 3399; Fax: +98 2188006544
Kropp and Fedorak, 1998; Van et al., 2003). Therefore, diesel fuel has been considered as priority pollutants which exert bio-hazardous effects on both human and other living organisms in the environment (Kramer and Van 1990; Refaat et al., 2008; Richardson, 1996). Fortunately, this mixture represents an excellent substrate in the study of hydrocarbon biodegradation due to its composition (Bicca et al., 1999). Among several clean-up techniques available to remove petroleum hydrocarbons from the soil and groundwater, bioremediation processes are gaining ground due to their simplicity, higher efficiency and cost-effectiveness when compared to other technologies (Alexander 1994; Ojo, 2006). These processes rely on the natural ability of microorganisms to carry out the mineralization of organic chemicals, leading ultimately to the formation of $\mathrm{CO}_{2}, \mathrm{H}_{2} \mathrm{O}$ and biomass (Duarte and Leite, 2000). The fate of petroleum hydrocarbons in the environment is largely controlled by abiotic factors which influence rates of microbial growth and enzymatic activities that determine the rates of petroleum hydrocarbon utilization (Leahy and 
Colwell, 1991; Ojo, 1995). The persistence of petroleum pollution depends on the quantity and quality of the hydrocarbon mixture and on the properties of the affected ecosystem. Although light petroleum products, like gasoline are efficiently removed by many physio-chemical methods, heavier fuels like diesel often require other techniques because of their low volatility. Since many naturally occurring microorganisms have the ability to utilize hydrocarbons as the sole source of carbon and are widely distributed (Koren et al., 2003), the biodegradation of these compounds is common in nature. Bacterial degradation of petroleum has been known for over 50 years, responsible bacteria have mostly been isolated from surface areas, such as soils, petroleum storage tanks and oil spills (Huy et al., 1999). There are numerous reports of isolation of petroleum hydrocarbon degrader bacteria from oil exposed areas (Kasai et al., 2001; Tazaki, 2005). Biodegradation of individual hydrocarbon compounds by pure bacterial strains has been studied extensively and metabolic pathways have been described (Heitkamp and Cerniglia, 1988; Gibson and Subramanian, 1984; Rehm and Reif 1981; Stirling and Watkinson, 1977). The ability to isolate high numbers of certain oil-degrading microorganisms from petroleum-contaminated environment is commonly taken as evidence that these microorganisms are the active degraders of that environment (Okerentugba and Ezeronye, 2003). However, no data exists on the findings of the diesel indigenous degrader bacterial isolates from oil refinery soils in Iran. For these reasons, the isolation and characterization of pure bacterial strains indigenous to the oil spill areas were carried out to obtain the exceptional pure bacterial strain in degrading the Iranian oil spill soils. In this study, the isolation and characterization of bacterial strains isolated from hydrocarbon-contaminated soils around the oil refinery in Tehran was investigated during the year of 2006 to 2008. The main objective of this paper is to describe the bacterial isolate strain, its ability to degrade and the genes involved in diesel degradation.

\section{MATERIALS AND METHODS}

Sampling site and enrichment cultures

The bacterial strains used in this study were isolated from petroleum hydrocarbon-contaminated soils around the oil refinery in Tehran, Iran. Five diesel oil contaminated soil samples were collected near the underground storage tanks and stored in closed containers at $4{ }^{\circ} \mathrm{C}$ prior to use. The soil samples were collected randomly from the top soil layer $(30 \mathrm{~cm}$ in depth). After removal of surface litter, samples were passed through a $2 \mathrm{~mm}$ sieve and stored at $4{ }^{\circ} \mathrm{C}$ in plastic bags. The commercial diesel fuel used for enrichment and biodegradation experiments were prepared from the petroleum refinery (Tehran, Iran).

All microbial enrichment and isolation were performed in the media prepared from the following composition (g/L): $\mathrm{NaNO}_{3}(7) ; \mathrm{K}_{2} \mathrm{HPO}_{4}(1) ; \mathrm{KH}_{2} \mathrm{PO}_{4}$ (0.5); $\mathrm{KCl}(0.1) ; \mathrm{MgSO}_{4}-7 \mathrm{H}_{2} \mathrm{O}(0.5) ; \mathrm{CaCl}_{2}(0.01)$; $\mathrm{FeSO}_{4}-7 \mathrm{H}_{2} \mathrm{O}(0.01)$. The medium was supplemented with $0.05 \mathrm{~mL}$ of trace elements solution of the following composition (g/L): $\mathrm{H}_{3} \mathrm{BO}_{3}(0.25)$; $\mathrm{CuSO}_{4}$ _5 $\mathrm{H}_{2} \mathrm{O}(0.5) ; \mathrm{MnSO}_{4}-\mathrm{H}_{2} \mathrm{O}(0.5) ; \mathrm{MoNa}_{2} \mathrm{O}_{4}-\mathrm{H}_{2} \mathrm{O}$ (0.06) and $\mathrm{ZnSO}_{4}-7 \mathrm{H}_{2} \mathrm{O}$ (0.7) (Mercade et al., 1996). Commercial diesel fuel was added as the sole carbon source to the autoclaved medium. The $\mathrm{pH}$ of the inorganic culture media was adjusted to 7.3 with either $\mathrm{HCl}$ or $\mathrm{NaOH}$.

\section{Diesel fuel extraction and analysis}

Total petroleum hydrocarbon (TPH) was measured with an infrared (IR) analyzer. The InfraCal Model CVH InfraCal TOG/TPH Analyzer (Wilks Enterprise CO.) is designed for use with EPA Methods 413.2 and 418.1 that use freon. With the discontinued use of Freon, other infrared transparent solvents, such as a hydrocarbon-free grade of perchloroethylene, AK-225 or S-316 may be used in the extraction procedure. This is quick and easy field and laboratory analysis method for determining TPH and, oil and grease concentration levels in soil and water (EPA, 1997). In this paper, perchloroethylene was used as an extraction solvent. TPH extraction from water was performed with the following method:

One tenth of the sample size of perchloroethylene was added to the sample collection container and then the $\mathrm{pH}$ of the sample was adjusted to less than 2 with 0.1 normal of hydrochloric acid. Then the result was shaken for 2 min with periodic venting to release excess pressure. After separation of phases, the solvent (lower) layer was passed from sodium sulfate (for removing water) and silica gel (for removing the polar organics). The purified extract was analyzed by infrared (IR) analyzer (Billets et al., 2001). 
Isolation and purification of diesel fuel-degrading bacteria

An enrichment culture technique was used to isolate diesel-degrading bacteria. The basal mineral medium (MM) containing soil and diesel was incubated at $35^{\circ} \mathrm{C}$ with orbital shaking (120 r/min). Enrichment of microbial culture was carried out in $300 \mathrm{~mL}$ erlenmeyer flasks containing $100 \mathrm{~mL}$ of MM. The $\mathrm{pH}$ was adjusted to 7.3. The MM was sterilized by autoclaving $\left(121^{\circ} \mathrm{C}\right.$ for $20 \mathrm{~min}$ ). The nutritive agar (NA) was used for isolation, numeration and maintenance of pure strains. The original soil sample $(1 \mathrm{~g})$ was added to $100 \mathrm{~mL}$ of MM containing $1 \mathrm{~g}$ of diesel fuel. At weekly intervals during the initial enrichment, transfers $(1 / 100 \mathrm{v} / \mathrm{v})$ were made to the same fresh medium. After six transfers, 1 $\mathrm{mL}$ was diluted and placed on agar plates and incubated for $48 \mathrm{~h}$ at $30^{\circ} \mathrm{C}$ in darkness. Ten diesel-utilizing bacteria were isolated by plating serial dilutions on NA. Cell morphology, mortality, Gram-reaction and physiological characteristics of the purified cultures were also checked by microscopic examination.

Experimental growth of bacterial strains and diesel fuel-biodegradation

All strains (TMY-1 to TMY-10) were tested for the ability to degrade diesel fuel and grow in an enrichment liquid medium. A series of $500 \mathrm{~mL}$ Erlenmeyer flasks were used for this experiment. Each flask contained $100 \mathrm{~mL}$ of $8 \mathrm{~g} / \mathrm{L}$ of nutrient broth plus diesel and culture was inoculated by transferring $3 \mathrm{~mL}$ of pre-culture (about $3 \times 108$ cells $/ \mathrm{mL}$ ) of strains, and initial $\mathrm{pH}$ was adjusted to 7.3. All biodegradation experiments were performed in various low (500 ppm) and high (10000 ppm) concentrations of commercial diesel fuel as the sole carbon and energy source. Ten experiments were designed in a batch reactor under aerobic condition by shaking on orbital shaker (rotation speed of $120 \mathrm{rpm}$ ) at room temperature $\left(28 \pm 2^{\circ} \mathrm{C}\right)$ for 15 days. For certainty, all treatments were performed in triplicate.

Samples were removed periodically to assess the concentration of the petroleum hydrocarbons by IR radiation with TPH meter (EPA, 1997) and bacterial growth was monitored by viable counts on nutrient agar plates (Amund and Igiri, 1990).

\section{Identification of the isolate}

The major physiological and biochemical tests were performed as described previously (Mata et al., 2002). Morphological and physiological characteristics of the best isolated strain were studied either on nutrient agar or in nutrient broth. Gram reaction, motility, shape and color of colony, catalase, urease, oxidase activities, nitrate reduction, esculin, tween 20 and 80 hydrolyzes and indol productions were checked as recommended by Smibert and Krieg (1994). Acid production from carbohydrates and sugars and utilization of carbon and nitrogen sources were evaluated as recommended by Ventosa et al. (1982). To determine the optimum temperature and $\mathrm{pH}$ for the growth of the strain, the cultures were incubated at a temperature range of 5-55 ${ }^{\circ} \mathrm{C}$ with intervals of $5{ }^{\circ} \mathrm{C}$ and $\mathrm{pH}$ values of 5-11. $\mathrm{pH}$ values below and above 6 were adjusted by sodium acetate and Tris-HCl buffer, respectively.

\section{Analyses of 165 rRNA sequences}

Genomic DNA of the isolate was extracted with a GenElute DNA extraction kit from Sigma. The 16S rRNA gene of isolate was amplified using the universal primers 8F (5'-AGAGTTTGATCCTGGCTCAG) and 1541R (50-AAGGAGGTGATCCAGCCGCA-3'). The amplification was done by initial denaturation at $95^{\circ} \mathrm{C}$ for $5 \mathrm{~min}$ followed by 10 cycles of $93^{\circ} \mathrm{C}$ for $1 \mathrm{~min}, 63^{\circ} \mathrm{C}$ for $1 \mathrm{~min}, 71^{\circ} \mathrm{C}$ for $1.5 \mathrm{~min}$; 20 cycles of $93^{\circ} \mathrm{C}$ for $1 \mathrm{~min}$, $67^{\circ} \mathrm{C}$ for $1 \mathrm{~min}, 71^{\circ} \mathrm{C}$ for $2 \mathrm{~min}$ and final extension at 71 ${ }^{\circ} \mathrm{C}$ for $5 \mathrm{~min}$. The purified PCR product was sequenced in both directions using an automated sequencer by SeqLab Laboratory (Germany). The phylogenic relationship of the isolate was determined by comparing the sequencing data with sequences of some members of the genus bacillus available through the GenBank database of the National Center for Biotechnology Information. The gene sequences of each isolate obtained in this study were compared with known $16 \mathrm{~s}$ rRNA gene sequences in the GenBank database.

\section{RESULTS AND DISCUSSION}

\section{Soil analysis}

The characteristics of the soil are presented in Table 1. The soil classification was sandy clay.

\section{Isolation of diesel-utilizing bacteria}

Ten strains of diesel-utilizing bacteria (TMY-1 to TMY-10) were isolated from petroleum contaminatedarea obtained at three sites in the Tehran oil refinery, Iran. The first experiment was carried out for determination of the ability of these strains on biodegradation of commercial diesel fuel at the concentration of $500 \mathrm{ppm}$ in an enrichment liquid 
Isolation and characterization of a novel native Bacillus strain

Table 1: Profile description of petroleum-contaminated soil

\begin{tabular}{lccccrrr}
\hline Physical appearance & Clay & Silt & Fine sand & Sand & Gravel & pH & TPH \\
\hline Quantity (\%) & 16 & 18 & 31 & 35 & 0 & $5.5-6.3$ & 0.51 \\
\hline
\end{tabular}

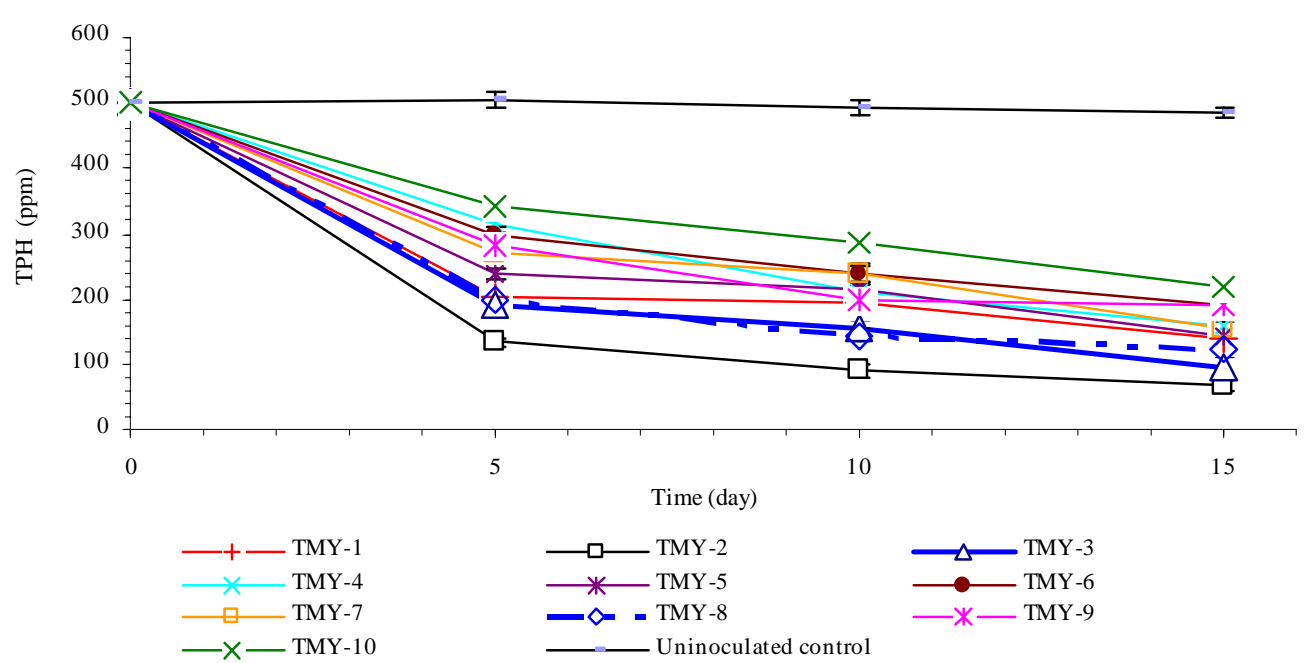

Fig. 1: Degradation of commercial diesel fuel by the ten isolates (TMY-1 to TMY-10). Each point represents the mean from triplicate data

medium. The laboratory experiment was designed in a batch reactor under aerobic condition by shaking on orbital shaker (rotation speed of $120 \mathrm{rpm}$ ) at room temperature $\left(25^{\circ} \mathrm{C}\right)$ and initial $\mathrm{pH}$ was adjusted to 7.3. The results of IR analyses of TPH shows that the addition of all bacteria strains enhance degradation of diesel fuel compared to the sample that was not supplemented with any bacteria strain. All strains were able to grow and degrade diesel oil between 56.41 to $86.67 \%$ (Fig. 1). The selection of candidate bacteria from ten strains isolated from the first stage efficiently was possible. The most significant reduction was seen when the media was inoculated with strain TMY-2 and TMY-3. The highest reduction by TMY-2 and TMY-3 was $86.67 \%$ and, $80.60 \%$, respectively. The biodegradation of diesel oil by all strains became very efficient during five-first days of inoculation; however efficiency was low until the fifteenth day. Two preselected efficient bacteria (TMY-2 and TMY-3) were able to grow well using diesel as the sole source of carbon. Among them, strain TMY-2 was the most efficient in degrading diesel. Two bacteria were streaked again onto fresh diesel-containing agar plates and nutrient agar plates to ensure purity. This experiment was performed to investigate the toxicity effect of the diesel fuel at high concentrations. Two pre-culture (about $10^{7}$ to $10^{8}$ cells/mL) efficient strains TMY-2 and TMY-3, selected at the first stage, were transferred at high concentration of commercial diesel fuel as the sole carbon and energy source (10000 ppm). The results of this evaluation are shown in Fig. 2. In this experiment, the biodegradation efficiency of TMY-2 and TMY-3 was obtained between $85.20 \%$ and $46.70 \%$, respectively. The TMY-2 reached the peak value after five days of inoculation and was remained constant until the end of the experiment (Day 15), until the fifteenth day, reaching the final biodegradation efficiency of $85.20 \%$. The total viable microbial population of TMY-2 and TMY-3 strains during biodegradation of commercial diesel fuel is presented in Fig. 3. Total viable counts of the TMY-2 $(5.00 \times 107 \mathrm{cfu})$ were much higher than the $8.00 \times 106 \mathrm{cfu}$ TMY-3 strain. After adding two strains, TMY-2 and TMY-3, unlike the TMY-3, the microbial population of TMY-2 immediately stimulated degraded diesel fuel accompanied by significant TPH degradation (Fig. 2), indicating that the TMY-2 strain utilized a portion of the C supplied by the diesel fuel as a potential nutrient source. Increases in microbial population of TMY-2 corresponded to decreases in TPH concentration during the same time period (Figs. 1 and 3). As shown in these Figs, the most significant reduction of diesel fuel was seen with TMY-2 strain.

Isolates TMY-2 was gram-positive, motile, facultative/ aerobic rods which grew at room temperature. According to the morphological and biochemical 


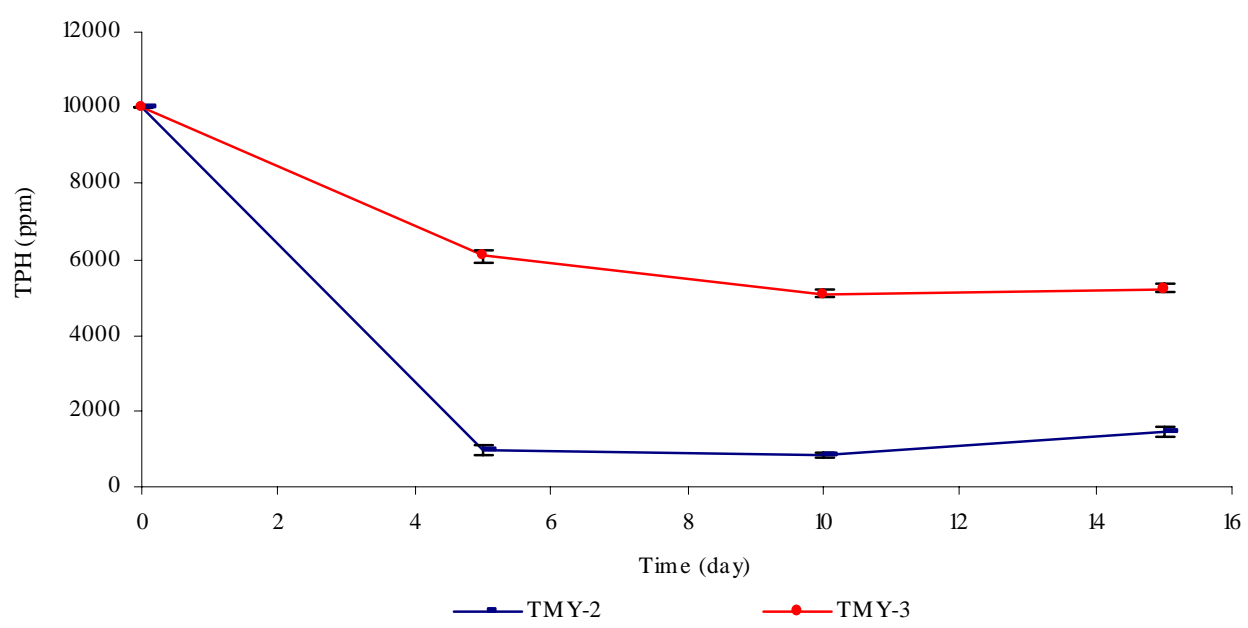

Fig. 2: Degradation of commercial diesel fuel by two isolates TMY-2 and TMY-3, each point represents the mean from triplicate data. Symbols: TMY-2 (-); TMY-3 (*)

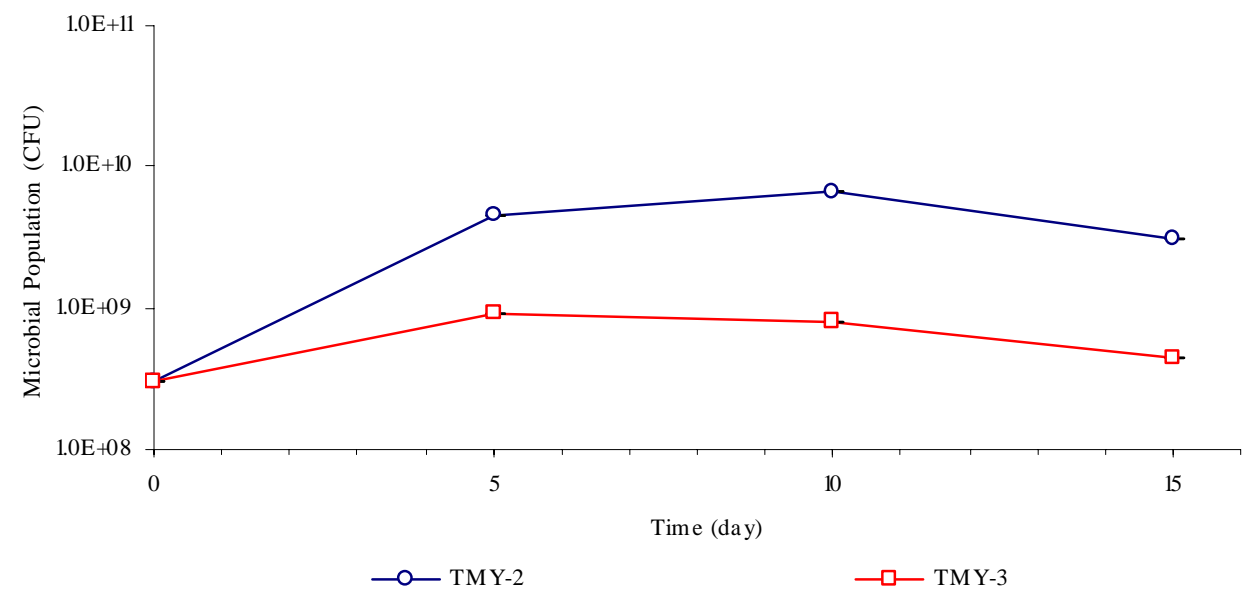

Fig. 3: Total viable microbial population during degradation of commercial diesel by TMY-2 and TMY-3 strains

properties, strains TMY-2 was tentatively classified as Bacillus sp. Partial sequencing of $16 \mathrm{~S}$ rRNA indicated that TMY-2 was a strain of Bacillus. Comparison of the 16S rRNA sequences of TMY-2 with those in the GenBank databases revealed a consistently high similarity (more than $98 \%$ similarity) with species of B.cereus and B.thuringiensis. Many studies on contaminated soils undergoing bioremediation were approved by Pseudomonas spp., but very few papers were reported on the roles of Bacillus sp. in hydrocarbon bioremediation. There are several reports of bioremediation of pollutants by the action of Bacillus sp. occurring in extreme environments. For example; 368 isolates belonging to the genus Bacillus were isolated from desert samples (Sorkhoh et al., 1993). Two strains of Bacillus degraded 80-89\% of crude oil (5 g/L) within five days at $60{ }^{\circ} \mathrm{C}$. In addition, Ijah and Antai (2003) reported Bacillus sp. being the predominant isolates of all the crude oil utilizing bacteria characterized from highly polluted soil samples (30\% and $40 \%$ crude oil). When five soil isolates were compared, it was seen that one Bacillus sp. COU-28 was the best oil degrader compared to isolates belonging to Micrococcus varians, P. aeruginosa, Vibrio sp. and Alcaligenes sp. (Ijah and Antai, 2003). Thereupon, Bacillus species are more tolerant to high levels of hydrocarbons due to their resistant endospores.

\section{Bacterial identification}

According to The Bergey's manual of systematic 


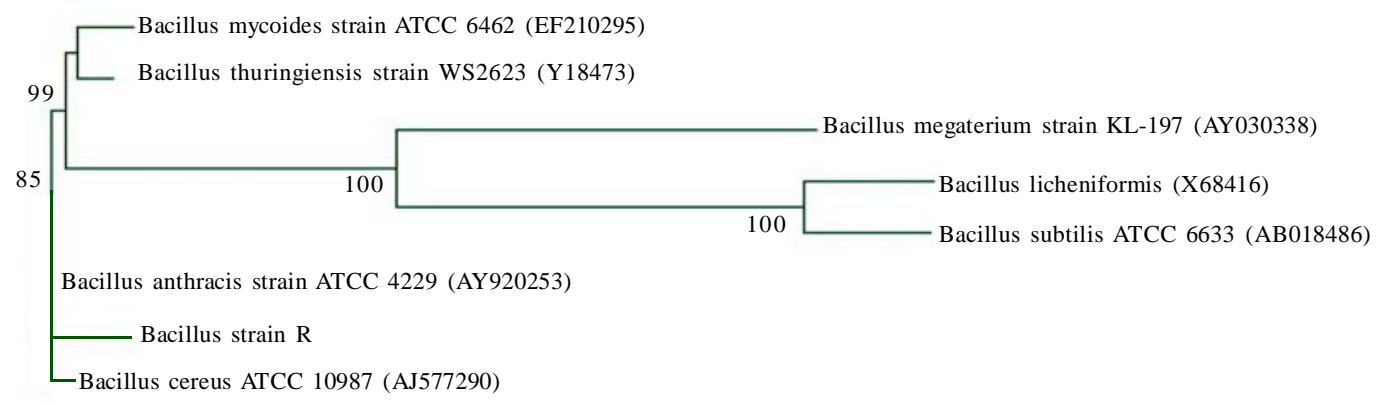

$\stackrel{\mapsto}{\mapsto}$

Fig. 4: Phylogenetic trees for the taxonomic location of strain TMY-2

Table 2: Morphological, biochemical and physiological characteristics of E28TMY-2 and TMY-3 strains

\begin{tabular}{|c|c|c|c|c|}
\hline Feature & TMY-2 & TMY-3 & B. cereus & B. Thuringiensis \\
\hline shape & Rod & Rod & Rod & Rod \\
\hline Spore & + & + & + & + \\
\hline Gram reaction & + & + & + & + \\
\hline Catalase & + & + & + & + \\
\hline Oxidase & + & + & - & $+/-^{(\mathrm{b})}$ \\
\hline Motility & + & + & $+/-^{(\mathrm{b})}$ & + \\
\hline $\mathrm{pH}$ range for growth & $6-11$ & $6-11$ & $5.6-6.8$ & $5.6-6.8$ \\
\hline \multicolumn{5}{|l|}{ Acid from: } \\
\hline D-Mannose & - & - & - & - \\
\hline D-Fructose & + & + & + & + \\
\hline Maltose & + & - & + & - \\
\hline Arabinose & + & - & - & - \\
\hline D-Glucose & + & - & + & + \\
\hline Lactose & - & - & - & - \\
\hline Galactose & - & - & $+/-^{(b)}$ & $+/-^{(\mathrm{b})}$ \\
\hline D-mannitol & + & - & - & - \\
\hline Sucrose & - & - & + & - \\
\hline D-Salicin & + & - & + & - \\
\hline \multicolumn{5}{|l|}{ Hydrolysis of: } \\
\hline Starch & - & - & + & + \\
\hline Tween 80, DNAse & - & - & $+/-^{(\mathrm{b})}$ & + \\
\hline DNAse & + & + & $+/-^{(\mathrm{b})}$ & + \\
\hline Gelatin & + & - & + & + \\
\hline Urease & + & - & $+/-^{(\mathrm{b})}$ & $+/-^{(\mathrm{b})}$ \\
\hline Indole production & - & - & - & - \\
\hline MR & - & - & - & - \\
\hline VP & + & - & + & $+/-^{(b)}$ \\
\hline \multicolumn{5}{|l|}{ Utilization: } \\
\hline Inulin & - & - & - & - \\
\hline D-fructose & - & + & + & + \\
\hline D-galactose & - & - & - & - \\
\hline Sucrose & - & - & - & - \\
\hline $\mathrm{H}_{2} \mathrm{~S}$ production & - & - & $\cdots \cdots$ & $\ldots \ldots$ \\
\hline Nitrate reduction & - & + & $\ldots \ldots$ & ..... \\
\hline Lactose & - & - & - & - \\
\hline
\end{tabular}

${ }^{a}+, 90-100 \%$ of strains are positive

${ }^{\mathrm{b}} 11-89 \%$ of strains are positive 
bacteriology and considering the physiological and biochemical tests performed, the strain was tentatively named as Bacillus sp. strain TMY-2. To confirm the identity of the isolate, PCR amplification and sequencing of the 16S rRNA gene were done. Dendrogram (Fig. 4) showing phylogenetic relationships derived from $16 \mathrm{~S}$ rRNA gene sequence analysis of strain TMY-2 with respect to Bacillus species with validly published names. The tree was constructed using the neighbour-joining (Felsenstein, 1993). Among the described sub species, the closest relative of isolate TMY-2 was Bacillus cereus. The strain TMY-2 was a spore-forming Gram-positive rod shaped, facultative anaerobic bacterium, which was motile by means of one or two subpolar flagella. This strain grew well at various concentrations of $\mathrm{NaCl}$ ranging from 0 up to $9 \%(w / v)$. The optimum growth was at $1 \%$ $(\mathrm{w} / \mathrm{v}) \mathrm{NaCl}$. The strain TMY-2 grew between 10 and $50^{\circ} \mathrm{C}$, with the optimum growth about $32-35^{\circ} \mathrm{C}$ and in a wide range of $\mathrm{pH}(5.0-11.0)$ with the optimum growth at initial $\mathrm{pH}$ values of 7.0-7.5. Colonies were smooth, circular, white-cream, entire, opaque and approximately $2 \mathrm{~mm}$ in diameter after 2 days at $34{ }^{\circ} \mathrm{C}$ on nutrient agar. Other characteristics that differentiate strain TMY-2 from related species are shown in Table 2.

\section{Identification of strains TMY-2}

To verify identification of TMY-2 as B. cereus or $B$. thuringiensis, this strain was characterized with phenotypic analysis. Strains TMY-2 was positive for catalase, oxidase, positive for urease and the VogesProskauer reaction and did not hydrolyze starch and tween 80. The details of other morphological and physiological characteristics are summarized in Table 2. Bacillus cereus and Bacillus spp. are widely distributed in nature (Drobniewski, 1993). Species of the genus Bacillus are rods, which sporulate in aerobic conditions. The endospores are resistant to heat, dehydration, or other physical and chemical stresses.

\section{CONCLUSION}

Degradation of hydrocarbons by environmental microflorae involves microorganisms having specialized metabolic capacities. In polluted environments, specialized microorganisms are abundant because of the adaptation of the microflorae to pollutant. It has also been shown that bacteria are the most predominant microorganism among other microorganisms in either in situ or ex situ bioremediation processes, indicating that bacteria are the main agents responsible for the degradation of diesel fuel.
This paper describes the first study on the isolation and characterization of commercial diesel-degrading bacterium from Iranian soils. Strain TMY-2 is a potential candidate for bioremediation of diesel fuel-contaminated sites. This efficiently degrading strain was characterized and identified as bacillus cereus or B. thuringiensis (more than $98 \%$ similarity). The use of native bacterial consortium with diesel utilizing capabilities as seed onto oilcontaminated environment could prove a more environmentally-friendly approach to bioremediation which would run enhance sustainable development rather than the use of exotic bacterial strains and chemicals.

\section{ACKNOWLEDGEMENTS}

The physiological and biochemical tests were conducted by Dr. Mohammad Ali Amoozegar, assistant Professor at the Department of Biology (Microbiology Unit) in the University of Tehran. The authors appreciate the financial support made by National Iranian Oil Products Refining and Distribution Company (NIORDC) and thank reviewers for their helpful suggestions in improving the manuscript.

\section{REFERENCES}

Alexander, M., (1994). Biodegradation and Bioremediation. San Diego, Academic Press, 453. ISBN: 0-12-049860-X.

Amund, O. O.; Igiri, C. O., (1990). Biodegradation of petroleum hydrocarbon under tropical estuarine conditions. World J. Microbiol. Biotechnol., 6 (3), 255-262 (8 pages).

Bicca, F. C.; Fleck, L. C.; Ayub, M. A. Z., (1999). Production of biosurfactant by hydrocarbon degrading Rhodococcus ruber and Rhodococcus erythropolis. Rev. Microbiol., 30 (3), 231-236 (6 pages).

Billets, S. N.; Topudurti, K.; Tay, S., (2001). Innovation technology verification report: Field measurement technology for Total Petroleum Hydrocarbons in soil. Wilks enterprise inc., Infracal TOG/TPH analyser. USEPA, Washington DC., EPA/600/R01/082.

Dean-Ross, D.; Moody, J.; Cerniglia, C. E., (2002). Utilization of mixtures of polycyclic aromatic hydrocarbons by bacteria isolated from contaminated sediment. FEMS Microbiol. Ecol., 41 (1), 1-7 (7 pages).

Drobniewski. F. A., (1993). Bacillus cereus and related species. Clin Microbiol Rev., 6 (4), 324-338 (15 pages).

Durand. J. P., Beboulene, J. J., Ducrozet, A., (1995). Detailed characterization of petroleum products with capillary analyzers. Analusis, 23 (10), 481-483 (3 pages).

Duarte da Cunha, C.; Gomes-Ferreira Leite, S., (2000). Gasoline biodegradation in different soil microcosms. Braz. J. Microbiol., 31 (1), 45-49 (5 pages).

EPA, (1997). Standard methods for evaluating solid waste: Physical/ chemical methods. Environmental Protection Agency. Publication, EPA 530/SW-846.

Felsenstein, J., (1993). PHYLIP (phylogenetic inference package). version 3.5c. Department of Genetics University of Washington, Seattle WA, USA. 
Gallego José, L. R.; Lordedo, J.; Llamas, J. F.; Vazquez, F.; Sanchez, J., (2001). Bioremediation of diesel-contaminated soils: Evaluation of potential in situ techniques by study of bacterial degradation. Biodegradation, 12 (5), 325-335 (11 pages).

Gibson, D. T.; Subramanian, V., (1984). Microbial degradation of aromatic hydrocarbons. In: Gibson, D.T. (Ed.), Microbial Degradation of Organic Compounds., Marcel Dekkar., New York, 181-252 (72 pages).

Heitkamp, M. A.; Cerniglia, C. E., (1988). Mineralization of polycyclic aromatic hydrocarbons by a bacterium isolated from sediment below an oil field., Appl. Environ. Microbiol., 54 (6), 1612-1614 (3 pages).

Huy, N. G.; Amada, K.; Haruki, M.; Hun, N. B.; Hang, D. T.; Ha, D. T. C.; Imanaka, T.; Morikawa, M.; Kanaya, S., (1999). Characterization of petroleum-degrading bacteria from oilcontaminated sites in Vietnam. J. Biosci. Bioeng., 88 (1), 100102 (3 pages).

Ijah, U. J. J; Antai, S. P., (2003). Removal of Nigerian light crude oil in soil over a 12-month period. Int. Biodeter. Biodegrad., 51, 93-99 (7 pages).

Kanaly, R. A.; Harayama, S., (2002). Biodegradation of highmolecular weight polycyclic aromatic hydrocarbons by bacteria. J. Bacteriol., 182 (8), 2059-2067 (9 pages).

Kasai, Y.; Kishira, H.; Syutsubo, K.; Harayama, S., (2001). Molecular detection of marine bacterial populations on beaches contaminated by the Nakhodka tanker oil-spill accident. Environ. Microbiol., 3 (4), 246-255 (10 pages).

Koren, O.; Knezevic, V.; Eliora, Z. R.; Rosenberg, E., (2003). Petroleum pollution bioremediation using water-insoluble uric acid as the nitrogen source. Appl. Environ. Microbiol., 69 (10), 6337-6339 (3 pages).

Kramer, P. G. N.; Van der Heijden, C. A., (1990). Polycyclic aromatic hydrocarbons (PAH): Carcinogenicity data and risk extrapolations. Toxicol. Environ. Chem., 16 (4), 341-451 (11 pages).

Kropp, K. G.; Fedorak, P. M., (1998). A review of the occurrence, toxicity, and biodegradation of condensed thiophenes found in petroleum. Can. J. Microbiol., 44 (7), 605-622 (18 pages).

Leahy, J. G.; Colwell, R. R., (1991). Microbial degradation of hydrocarbons in the environment. Microbiol. Rev., 54 (3), 305-315 (11 pages).

Mata, J. A.; Martínez-Cánovas, J.; Quesada, E.; Béjar, V., (2002). A detailed phenotypic characterisation of the type strains of Halomonas species. Syst. Appl. Microbiol. 25 (3), 360-375

\section{(16 pages).}

Mercade, M. E.; Monleom, L.; De Andres, C. ; Rodon, I.; Martinez, E.; Espuny, M. J.; Manresa, A., (1996). Screening and Selection of Surfactant-producing bacteria from waste lubricating oil. J. Appl. Bacteriol., 81 (2), 161-166 (6 pages).

Ojo, O. A., (2006). Petroleum-hydrocarbon utilization by native bacterial population from a wastewater canal Southwest Nigeria. Afr. J. Biotechnol., 5 (4), 333-337 (5 pages).

Okerentugba, P. O.; Ezeronye, O. U., (2003). Petroleum degrading potentials of single and mixed microbial cultures isolated from rivers and refinery effluents in Nigeria. Afr. J. Biotech., 2 (9), 288-292 (5 pages).

Rehm, H. J.; Reif, I., (1981). Mechanisms and occurrence of microbial oxidation of long- chain alkanes. $1^{\text {st }}$ Ed. Springer Berlin/Heidelberg, 175-215 .

Refaat, A. A.; Attia, N. K.; Sibak, H. A.; El Sheltawy, S. T.; El Diwani, G. I., (2008). Production optimization and quality assessment of biodiesel from waste vegetable oil. Int. J. Environ. Sci. Tech., 5 (1), 75-82 (8 pages).

Richardson, M., (1996). Environmental Xenobiotics. CRC Press, 11-18.

Smibert, R. M.; Krieg, N. R., (1994). Phenotypic characterization. in methods for general and molecular bacteriology. American Society for Microbiology, 611-651.

Sorkhoh, N. A.; Ibrahim, A. S.; Ghannoum, M. A.; Radwan, S. S., (1993). High temperature hydrocarbon degradation by Bacillus stearothermophilus from oil-polluted Kuwait desert., Appl. Microbiol. Biotech., 39 (1), 123-126 (4 pages).

Stirling, L. A.; Watkinson, R. J., (1977). Microbial metabolism of alicyclic hydrocarbons: Isolation and properties of a cyclohexane-degrading bacterium. J. Gen. Microbiol., 99 (1), 119-125 (7 pages).

Tazaki, K.; Chaerun, S. K.; Asada, R.; Kogure, K., (2005). Interaction between clay minerals and hydrocarbon-utilizing indigenous microorganisms in high concentration of heavy oil: Implications for bioremediation. Clay Miner., 40 (1), 105114 (10 pages).

Van Hamme, J. D.; Singh, A.; Ward, O. P., (2003). Recent advances in petroleum microbiology. Microbiol. Molecul. Bio. Rev., 67 (4), 1092-2172 (81 pages) .

Ventosa, A.; Quesada, E.; Rodriguez-Valera, F., (1982). Numerical taxonomy of moderately halophilic Gram-negative rods. J. Gen. Microbiol., 128 (9), 1959-1968 (10 pages).

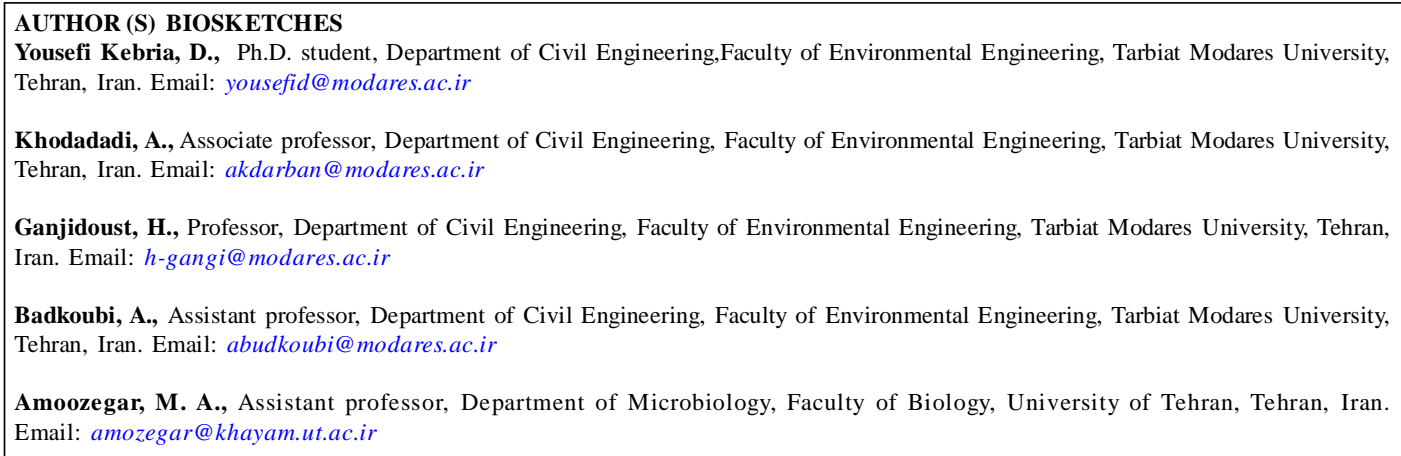

Khodadadi, A., Associate professor, Department of Civil Engineering, Faculty of Environmental Engineering, Tarbiat Modares University, Tehran, Iran. Email: akdarban@modares.ac.ir

Ganjidoust, H., Professor, Department of Civil Engineering, Faculty of Environmental Engineering, Tarbiat Modares University, Tehran, Iran. Email: h-gangi@modares.ac.ir

Badkoubi, A., Assistant professor, Department of Civil Engineering, Faculty of Environmental Engineering, Tarbiat Modares University, Tehran, Iran. Email: abudkoubi@modares.ac.ir

Amoozegar, M. A., Assistant professor, Department of Microbiology, Faculty of Biology, University of Tehran, Tehran, Iran. Email: amozegar@khayam.ut.ac.ir 